ISSN 1816-6075 (Print), 1818-0523 (Online)

Journal of System and Management Sciences

Vol. 9 (2019) No. 1, pp. 117-140

DOI:10.33168/JSMS.2019.0107

\title{
Using TOPSIS Method for Assessing the Commercial Potential of Biotechnologies
}

\author{
Vaida Zemlickienè \\ Institute of Sustainable Construction, Vilnius Gediminas Technical University, Vilnius, Lithuania \\ E-mail:vaida.zemlickiene@vgtu.lt
}

\begin{abstract}
In the course of research has been established, that specifics of different technology manufacturing branches are important for assessing the commercial potential. Over the last decade, the analysis of the tools on a global scale led to the unequivocal conclusion - so far developed methodical basis has suffered lack of maturity for its practical use in business, a need for assessing commercial potential at an early stage of biotechnology commercialization has been ignored. The scientific literature of the last years did not take into account the specific of biotechnologies. This aspect was taken into account in the process designing the set of factors, determining the significance and the values of the factors. The model applies multiple criteria methods the selection of which has been determined by the motive related to the goal of assessment - to assess and rank the compared objects. This article discusses in detail application processes of the TOPSIS for assessment the commercial potential of biotechnologies. Further, the values and significance of the factors are combined into a single criterion of multiple criteria evaluation using TOPSIS (Technique for Order of Preference by Similarity to Ideal Solution) methods.
\end{abstract}

Keywords: assessing the commercial potential of biotechnologies, multiple criteria decision making methods, TOPSIS.

\section{Introduction}

Ever since ancient times, almost without any exception, in order to create or invent all necessary tools and reach technological solutions, scientific experiments and ongoing knowledge development have been employed. By the 
time when modern economic principles are beyond the concept based on natural resources, knowledge has become a major economic and social stimulus. Technology development and its application for human activities - R\&D - have been recognized as the basis of economic performance, a source of technological solutions and of high value-added supply both in scientific literature as well as in the strategic documents of the Government and international organizations.

However, most of the attempts to commercialize technologies ends in failure, and thus the ability to timely and objectively assess the expedience of technology commercialization, in order to avoid non-productive investments, is a crucial and unsafe move for the institutions engaged in scientific research and $R \& D$, when the owner of technology, the potential investor or buyer must take a decision on the future of technology and to answer questions such as 'if it is worth developing this technology, investing in it or buying it'. In order to answer these questions and to make the right decision, tools for assessing the commercial potential of technologies are in use. Scientific literature (Cooper 2009; Rahal 2005; Cho, Lee 2013; Price et al. 2008; Dereli, Altun 2013; Bandarian 2007) and information sources provided by different organizations (WIPO 2005; EPO 2012; NASA 2017; VentureQuest Ltd 2015; International Islamic University Malaysia 2017) allow to examine the methods and models assessing the commercial potential of technologies recommended. The analysis of the tools on a global scale led to the unequivocal conclusion - so far developed methodical basis has suffered from lack of maturity for its practical use in business, a need for assessing commercial potential at an early stage of technology commercialization has been ignored and the assessment of commercial potential has not considered the specificity of different technology manufacturing branches, this article addresses the case of biotechnology. Lack of relevant theoretical solutions can be seen as a scientific problem that requires scientific research. In order to ensure the harmonious activity of the institutions engaged in $R \& D$ and avoid failure in the commercialization process, an advanced tool for verifying decisions on 
technology development at early stages of commercialization, i.e. an instrument for assessing commercial potential for biotechnology, is needed.

This article discusses in detail the application the TOPSIS method the selection of which has been determined by the motive related to the goal of assessment to apply quantitative methods for assessing and ranking the comparing biotechnology. The main idea of MCDM methods is to combine the values and significance of factors into a single criterion of multi criteria evaluation (Hwang, Yoon 1981, Ustinovičius et al. 2007).

\section{Description of the model for assessing the commercial potential of biotechnologies}

The first stage of the model's development process - development a set of factors for assessment commercial potential of biotechnologies (Fig. 1). A universal set of factors for assessing the commercial potential of technology has been used to create a set factors of biotechnology (Zemlickienè, 2015). The following aspects of biotechnology commercialization have been taken into account in the development process of the new set of factors for biotechnology: 1) duration of development period: development is a restricted by slow biological and biurocratic processes. The normal duration of a product development at least 710 years, in some cases up to $12-15$ years; 2) the impact of the patenting process for the development process: steps while the technology reaches the market usually takes up a significant part of the useful period of patent protection; 3) biotechnology research is very expensive and requires adequate infrastructure and reagents; 4) high cost and risk causes difficult attraction of investments; 5) risks in biotechnology projects manifests itself in two aspects: enormous costs are often unsuccessful if technology is not validated at one of the validation phases; confidentiality is essential for biotechnology projects and should be maintained for a long period of time. During such time, the risk of disclosure of technology is high. 


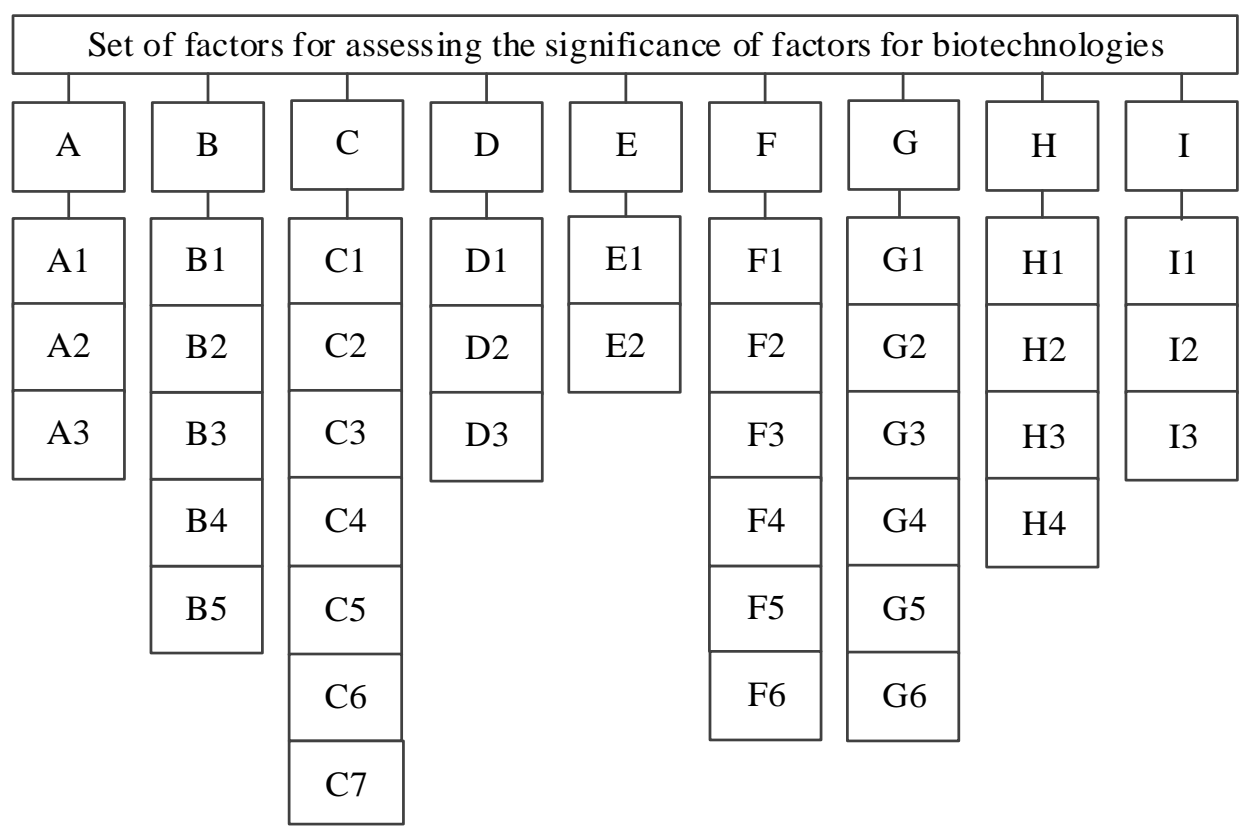

Fig. 1. System of factors used for commercial potential assessment of biotechnology.

Source: author.

Table 1. Description of factors meanings in set of factors

\begin{tabular}{|l|l|}
\hline Factors groups & Factors \\
\hline $\begin{array}{l}\text { A - situation on the } \\
\text { market }\end{array}$ & $\begin{array}{l}\text { A1-target market share of the potential product at the } \\
\text { technology assessment moment; } \\
\text { A2-level of the customer's needs regarding the potential } \\
\text { product; } \\
\text { A3-level of the readiness of the market for the product; }\end{array}$ \\
\hline $\begin{array}{l}\text { B - value for the } \\
\text { consumer }\end{array}$ & $\begin{array}{l}\text { B1-predicted offered value for the consumer; } \\
\text { B2-feedback of target customers regarding product } \\
\text { concept; } \\
\text { B3-level of the uniqueness of the value provided to the } \\
\text { potential user of product/technology; } \\
\text { B4-level of experiencing difficulty in use the potential } \\
\text { product; } \\
\text { B5-relative advantage of the potential product; }\end{array}$ \\
\hline $\begin{array}{l}\text { C-financial } \\
\text { environment }\end{array}$ & $\begin{array}{l}\text { C2-the potential to finance; } \\
\text { C3-predicted contribution of technology to the profit of the } \\
\text { company; } \\
\text { C4-predictable period for covering costs of the project on } \\
\text { technology commercialization; } \\
\text { C5-impact of the potential product durability in order to } \\
\text { create a renewable source of income; }\end{array}$ \\
\hline
\end{tabular}




\begin{tabular}{|c|c|}
\hline & $\begin{array}{l}\text { C6-predicted period of product development; } \\
\text { C7-accessibility of the infrastructure for product } \\
\text { development. }\end{array}$ \\
\hline $\begin{array}{l}\text { D-competitive } \\
\text { environment }\end{array}$ & $\begin{array}{l}\text { D1-the predicted lifetime of technology; } \\
\text { D2-ability to copy technology; } \\
\text { D3-intensity of competition. }\end{array}$ \\
\hline $\begin{array}{l}\text { E-technology } \\
\text { features }\end{array}$ & $\begin{array}{l}\text { E1-complexity of technology; } \\
\text { E2-dependence of technology functioning on geographical } \\
\text { /climatic circumstances; }\end{array}$ \\
\hline $\begin{array}{l}\text { F-competence of } \\
\text { technology } \\
\text { developers and relate } \\
\text { opportunities }\end{array}$ & $\begin{array}{l}\text { F1-competence of specialized engineering staff; } \\
\text { F2-competence of marketing personnel; } \\
\text { F3-competence of technology transfer personnel; } \\
\text { F4-competence of sales personnel; } \\
\text { F5-competence of the production unit; } \\
\text { F6-accessibility of specialized engineering staff. }\end{array}$ \\
\hline G-legal environment & $\begin{array}{l}\text { G1-benevolence of national legislation for } \\
\text { commercialization; } \\
\text { G2-utilization potential of technology; } \\
\text { G3-novelty of technology; } \\
\text { G4-significance of improvement on prior art - difference } \\
\text { compared to the analogue; } \\
\text { G5-price for legal protection; } \\
\text { G6-the influence of legal protection for the development } \\
\text { of technology. }\end{array}$ \\
\hline H-inventor/-s profile & $\begin{array}{l}\text { H1-inventor's experience in technology } \\
\text { commercialization; } \\
\text { H2-inventor's academic recognition; } \\
\text { H3-inventor's predicted level of involvement as a team } \\
\text { member in technology commercialization; } \\
\text { H4-inventor's financial contribution to technology } \\
\text { commercialization. }\end{array}$ \\
\hline $\begin{array}{l}\text { I-internal policy of } \\
\text { the institution }\end{array}$ & $\begin{array}{l}\text { I1-compliance of the project on technology with strategy } \\
\text { of organization; } \\
\text { I2-acceptance of the organization strategy of } \\
\text { commercialization for the inventor; } \\
\text { I3-image of the organization in the area of technology } \\
\text { commercialization. }\end{array}$ \\
\hline
\end{tabular}

The significance of factor groups and factors (Fig. 2) have been determined on the basis of the system factors for assessing the commercial potential of biotechnologies (Fig. 1). In order to do this, an expert evaluation questionnaire was designed and a expert survey was conducted. For survey was selected 
officials from WIPO in Geneva, EPO in Munich and few technology transfer centres of university's in Berlin and Munich. The surveyed experts were selected considering: 1) experience in the process of biotechnology commercialization; 2) experience in institution responsible for the promotion and control of technology commercialization. Following stage of the survey focus was switched on listening to the position of the experts on the significance of factors.

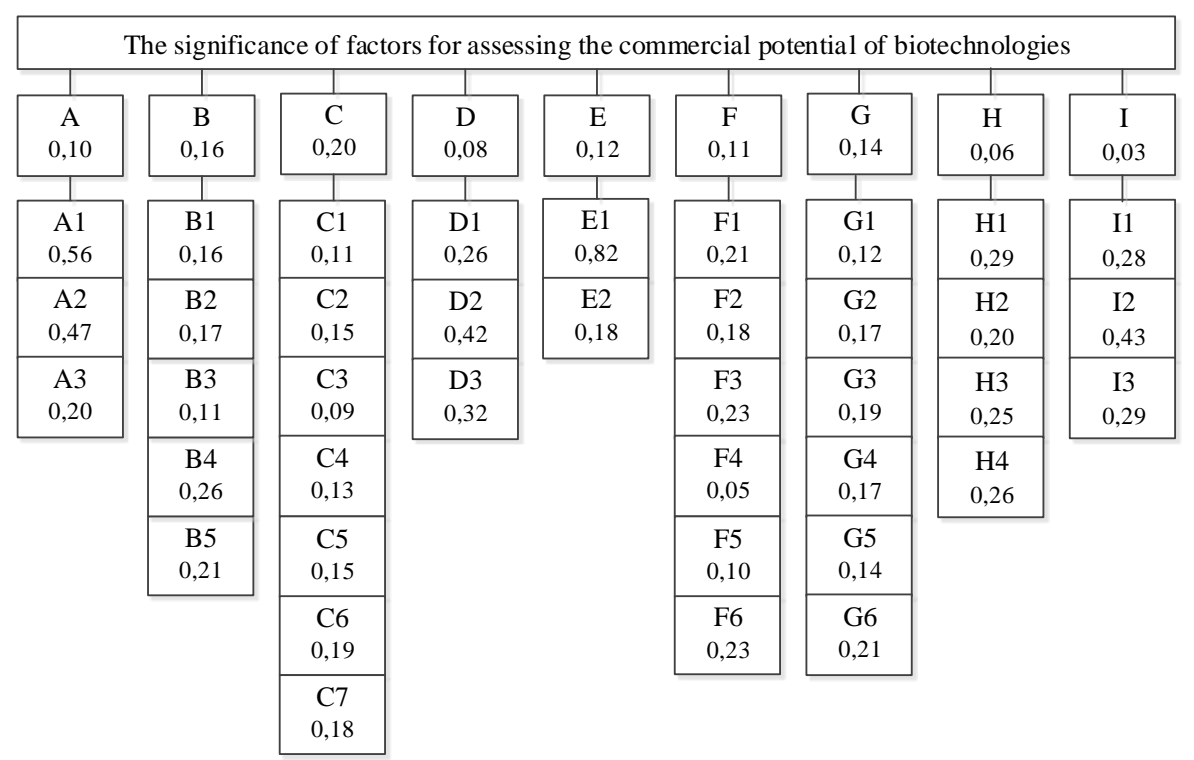

Fig. 2. The significance of factors for assessing the commercial potential of biotechnology. Source: author.

The formation of the meanings of factor values covers the preparation of the assessment scale for every factor indicated in the system, which is a measure for an evaluator of technology in the process of technology assessment. The preliminary meanings of factor values were defined by the author on the grounds of scientific and professional literature and statistics. At the second stage of research, the meanings of factor values were specified by the experts and expressed by five-point factor-characterizing dimension scales (Appendix 1). 
The first stage of biotechnology assessment includes an evaluator selects a value in the scale; next, the values are combined with the significance of factors into a single criterion of multi-criteria evaluation. To accomplish the objective the relevant information is required, which has to be related to the current situation on the market as well as the existing situation inside the establishment. Thus, on the condition, if the available information is considered to be insufficient or of inadequate quality, the research on marketing as well as the analysis of the internal information have to be provided.

During the final stage of the assessment the calculations have to by performing by the selected method, when the derived values of factors and significance of factors were used, the mathematical evaluation was conducted and the obtained results were analysed, afterwards the ranking and decision making was provided.

\section{Selection of the method for combining the values and significance of factors into a single criterion of multiple criteria evaluation on the commercial potential of technologies}

The process of assessing the commercial potential of technologies is considered to be very influential for the results of the production in those fields of industrial enterprises which require a precise and responsible approach for selecting the appropriate method in order to combine the values of factors and their significance. The practical application of the judgements in terms of the expedience of commercialization of technologies is frequently accepted by providing rather primitive methods, although in rare cases more advanced methods of assessment could be used; however, they are limited by the availability of the information, required for the methods to be determined and evaluated. Besides that, the available scientific publications and literature sources most frequently deal with the ideas how to work out the set of the factor groups regarding the commercial potential of technologies and how to determine the 
methods of the significance of factors. In this respect, the choice of the method in terms of combining the values and significance of factors appear to be rather complicated. The majority of attributes provide the possibilities for the investigation of the multi-criteria method application for a particular goal. Thus, to select a suitable and appropriate method, the following analysis has to be carried out on:

-the number of a particular type of tasks solved by means of the method;

-the maximum possible number of the alternatives assessed;

-the maximum possible number of factors characterizing the alternatives;

-the information on the opinion of the experts who make decisions;

-the possibilities of reliability analysis of the obtained results;

-the time allocated for training of the new personnel;

-the time allocated for the solution of the task (Zavadskas, Kaklauskas 1996).

In accordance with the type of the available initial data, used in setting the rating of the alternatives, the multi-criteria methods for the approval of the decision could be classified into deterministic, stochastic and fuzzy set theory methods (Triantaphyllou 2000). Taking into consideration, the number of people participating in the process of decision making, the methods are divided into: a single person decision making and group decision making (Triantaphyllou 2000). Such scientists as Chen and Hwang (1992) divide deterministic MDCM methods of a single person into the categories according to the type of information and its accessibility. Z. Turskis (2009) provides the classification of multi-criteria assessment method taking into account the information available for a decision maker as well in terms of the specificity of information.

When analysing scientific and professional literature sources, where there are presented tools for the evaluation of the commercial potential of technologies, the most noteworthy method recommended for application is IPscore ${ }^{\circ} 2.0$ program provided by the European Patent Office (EPO) (2012), which is considered to be the most complicated and upgraded method from the point of view of the input designated for the assessment of the commercial potential of technologies, The 
judgements derived from the context indicate that one method from a number of multiple-criteria methods could be used for combining the values of factors and significance. The tool applied by „VentureQuest Ltd“(2015) for determining the feasibility of commercialization of technologies is based on the multiple criteria decision making methods. The groups with six factors are used for the purpose of assessing. They are comprised of a certain number of factors; ten-point scale is used to specify the values of the system of factors. A. D. Rahal (2005) presented in his thesis the results of the research, the purpose of which was aimed to determine the latest factors influencing the licensing of technology and the comparative significance of each factor. To summarize the results the logistic regression method was applied. International Islamic University Malaysia (2013) applies the significance of factors for the evaluation of new inventions as well as for the commercial potential of technologies. J. Cho and J. Lee (2013) introduce in their research study the model for the evaluation of the latest products of technology for the assessment of the possibilities of commercialization. Based on the results of the literature review and by means of Delphi method, four areas related to decision making are determined, subsequently sixteen factors are selected, taking into account their priority by means of fuzzy analytic hierarchy process method based on the unspecified figures. R. Bandarian (2007) affirms that Strategic Technology Evaluation Program (STEP) is the most applicable tool which could help to assess the latest technology during its early stage of originating. Cincinnati University applies STEP method, which is based on the questionnaire, indispensable for decision making and which allows to evaluate the significance of the indicated factors. Robert G. Cooper (2009) promotes the idea that the participation of Top Level Managers responsible for diverse fields of enterprise activities are required in the assessment of the commercial potential of technologies such as finance, marketing, sales, manufacturing and etc. The evaluation is performed taking into consideration six factors according to the scale from 0 to 10 . The attractiveness of the project is evaluated as weighted and un-weighted taking into account the value of six factors (when determining the 
averages of the assessing presented by all the evaluators) and by 100 points scale. The obtained evaluation of 60/100 most frequently indicates a positive decision making.

When summarizing the analysis, it is possible to state, that the assessing of the commercial potential of technologies is frequently provided by applying completely primitive methods based on the majority of votes of the Top Level Managers or the evaluation results made by few evaluators and validated by the multiplication of values and significance of factors. In rare cases, the multicriteria analysis methods are provided, but in majority cases it is difficult to decide which particular method has to be applied in one or another case. If multicriteria methods of assessing are used, then among the most frequently applied forms of tools for assessing is considered to be the so called program; however the available information is dedicated only to a user who applies the tool and who is an evaluator as well, namely the guidelines how to use the program and thus, the judgements are usually made only with the reference to the context.

The area of multi-criteria analysis has not been finally developed so far and the methods applied are not absolutely perfect ones, therefore not a single method of multi-criteria decision making is considered to be the best and could be provided for the solution of all the problems. Several approaches have been recommended in selecting the most suitable method of multi-criteria decision making for very particular problems. Guitouni and Martel (1998) suggested paying attention to the most meaningful processes of multi-criteria decision making method when selecting it, namely the input of data, the complexity of both modelling (links) and calculation and data output (Ishizaka, Nemery 2013). To reduce the influence of the specificity of separate multiple criteria methods of assessing on the results of calculations, it is appropriate to evaluate the investigated phenomenon by several methods, then to determine the average of evaluations (Zavadskas, Turskis 2008; Andriušaitienė et al. 2008; Ginevičius, Podvezko 2004). Thus, there are partially eliminated the disadvantages of separate methods of assessing and the final findings are objectified. 
To solve the problems of assessing of commercial potential of technologies the methods of multi-criteria assessing have been chosen, the application of which provide quantitative and qualitative information. Because of the little insignificance of the scientific and professional input, regarding the models used for the assessment of the commercial potential of technologies and for the selection of the appropriate methods for the value of factor of the commercial potential of technologies as well as for combining the significance, there have been considered the methods applied in the other fields of technology (Zavadskas et al. 2008). There have been selected TOPSIS methods, which allow the manifold evaluation of the technologies taking into consideration the amount of the available information as well as its possibilities.

\section{Combining of values and significance of factors into a single criterion of multiple criteria evaluation using TOPSIS}

The main principal of TOPSIS method is to determine the alternative which has the common smallest distance from the values of the best criteria as well as the largest distance from the worst values (Jahanshahloo et al. 2006) . The method does not require to minimize (of the maximized) the reorganization of the criteria into the maximized ones (minimized ones) (Ginevičius, Podvezko 2008; Tzeng, Huang 2011).

To determine the proximity for an ideal point by TOPSIS method (Hwang, Yoon 1981) the ideal best $A_{p}$ alternative and the ideal worst $A_{b}$ alternative are compiled; the relative distance of the analysed alternative from them is searched.

Stage 1. The initial matrix $\mathrm{X}$ of decision making is compiled (1).

Stage 2. The significance $w_{j}$ of factors is applied to solve multi-criteria discrete problems and are calculated according to the equation (2).

Stage3. Matrix X for decision making is normalized according to the equation: 


$$
\bar{x}_{i j}=\frac{x_{i j}}{\sqrt{\sum_{i=1}^{m} x_{i j}^{2}}} .
$$

where $\bar{x}_{i j}$-is the value of the normalized indicator $\mathrm{j}$ of $\mathrm{i}$ alternative; $x_{i j}$-are members of the decision making matrix; $x_{i j}-$ is the value $\mathrm{i}$ of the decision indicator of the alternative $\mathrm{j} ; i=1,2, \ldots, m-$ is the number of the alternatives; $j=1,2, \ldots, n-$ is the number of the values of factors.

Stage 4.The weighted normalized decision making matrix is compiled:

$$
\hat{x}_{i j}=\bar{x}_{i j} w_{j}
$$

Stage 5. The matrix of the ideal best and ideal worst alternatives is compiled. The ideal best alternative is chosen, namely the best values of each factor are included into the matrix from all the alternatives.

When the best value $\hat{x}_{p j}$ of a factor is accepted as maximum (in the analysed case, the best values of all factors are maximum),

$$
\hat{x}_{p j}=\max _{i} x_{i j}
$$

When the best value $\hat{x}_{p j}$ of a factor is minimum, then the equation is:

$$
\hat{x}_{p j}=\min _{i} x_{i j}
$$

The ideal worst alternative is chosen, namely the worst values of each factor are taken from all the alternatives. When the worst value $\hat{x}_{b j}$ of a factor is minimum one (in the analysed case all the worst values of the factors are minimum), then the following is written:

$$
\hat{x}_{b j}=\min _{i} x_{i j}
$$

When the worst value $\hat{x}_{b j}$ of a factor is maximum, then:

$$
\hat{x}_{b j}=\max _{i} x_{i j}
$$

Stage 6.The distance of each alternative is found from the ideal best alternative. Hwang and Yoon (1981) by applying TOPSIS method suggested three varieties 
of the analysis to be used in calculating the distance, namely in the linear space, Euclidean and Minkovskij space. The calculation of a distance has been accepted as the best widely applied for the calculation of the distance in the Euclidean space. The distance from the ideal best alternative $d_{p i}$ is calculated by the equation:

$$
d_{p i}=\sqrt{\sum_{j=1}^{n}\left(\hat{x}_{i j}-\hat{x}_{p j}\right)^{2}}
$$

Stage 7.The distance from the ideal worst alternative $d_{b i}$ is calculated according to the formula:

$$
d_{b i}=\sqrt{\sum_{j=1}^{n}\left(\hat{x}_{i j}-\hat{x}_{b j}\right)^{2}} .
$$

Stage 8 . The relative distance of each alternative is calculated from the ideal worst alternative $K_{i}$ according to the formula:

$$
K_{i}=\frac{d_{b i}}{d_{p i}+d_{b i}}
$$

Stage 9. The rating is provided for the alternatives according to the obtained values. If $K_{i}$ has higher value, then the alternative is moved more away from the ideal worst alternative, namely the alternative appears to be more preferable.

\section{Conclusions}

It has been concluded that in order to assess the commercial potential of biotechnologies, in a majority of cases, rather primitive methods have been applied, and in rare cases the multi criteria analysis methods have been provided. Moreover, the scientific and professional input in terms of assessing of the commercial potential of biotechnologies in majority cases appears to be of insignificant use when selecting the appropriate methods for the values of the factors of the commercial potential of technologies and significance to be combined together. 
The research study has been provided in order to choose the multi criteria assessment structure to be able to work out and apply the model, consequently determined by the motive related to the objective of the research study and for pursuing the compiling of the model for assessing of the commercial potential of biotechnologies and for the evaluation of the relevant technologies from the point of view of the commercial potential.

Guided by the analysis of the scientific literature sources as well as the accomplished expert investigation, the set of factors for assessing of the commercial potential of biotechnologies has been provided, the values of factors have been derived. During the second stage of the research study, the significance of the factors and groups of factors in the set has been determined which tends to expose the impact of the groups of factors as well as factors on the assessed object under the consideration. After assessing the groups of factors and factors, the significance have been withdrawn, which have been subsequently ranked. The results of the assessment of the factor groups as well as the rating order are provided: 1 - financial environment $(C=0,20) ; 2$ - value for the consumer $(B=$ $0,16) ; 3$ - legal environment $(\mathrm{G}=0,14) ; 4$ - technology features $(\mathrm{E}=0,12) ; 5$ competency of technology developers $(\mathrm{F}=0,11) ; 6$ - situation on the market (A $=0,10) ; 7$ - competitive environment $(\mathrm{D}=0,08) ; 8$-inventors profile $(\mathrm{H}=0,06)$; 9 - internal policy of the institution $(I=0,03)$.

\section{Acknowledgement}

This project has received funding from European Social Fund (project No 09.3.3LMT-K-712-02-0201) under grant agreement with the Research Council of Lithuania (LMTLT). 


\section{References}

Andriušaitienė, D.; Ginevičienė , V. B.; Šileika, A. 2008. Daugiakriterinis profesinio mokymo kokybès valdymo vertinimo modelis, Verslas: teorija ir praktika 9(2): 88-96.

Bandarian, R. 2007. Evaluation of commercial potential of a new technology at the early stage of development with fuzzy logic, Journal of Technology Management 2: 73-85.

Cho, J.; Lee, J. 2013. Development of a new technology product evaluation model for assessing commercialization opportunities using Delphi method and fuzzy AHP approach, Expert Systems with Applications 40(13): 5314-5330. https://doi.org/10.1016/j.eswa.2013.03.038

Cooper R. G. 2009. How companies are reinventing their idea-to-launch methodologies. Research Technology Management, Product Development institute Inc.

Dereli, T.; Altun, K. 2013. A novel approach for assessment of candidate technologies with respect totheir innovation potentials: quick innovation intelligence process, Expert Systems with Applications40(3): 881-891. https://doi.org/10.1016/j.eswa.2012.05.044

EPO (European Patent Office), IPscore® 2.0program provided by the European Patent Office. 2017.[online],[cited 7 September 2017]. Available from Internet:https://www.epo.org/searching-for-patents/business/ipscore.html\#tab-1

Jahanshahloo, G.R.; Lotfi, F.H.; Izadikhah, M. Extension of the TOPSIS method for decision-making problems with fuzzy data. Appl. Math. Comput. 2006, 181, $1544-1551$. 
Ginevičius, R.; Podvezko, V. 2004, Assessing the Accuracy of Expert Methods, Inžinerinė Ekonomika-Engineering Economics 40, pp. 7-12.

Hwang, C. L.; Yoon, K. 1981. Multiple Attribute Decision Making Methods and Applications. Berlin: Springer-Verlag.

International Islamic University Malaysia. 2017. [online], [cited 7 September 2017]. Available from Internet: http://www.iium.edu.my/irie/13/index.php/evaluation-criteria/8-iriie/15commercial-potentialaward

G. Lee, K. S. Jun, and E.-S. Chung, Robust spatial flood vulnerability assessment for Han River using fuzzy TOPSIS with cut level set, Expert Systems with Applications, vol. 41, no. 2, pp. 644-654, 2014.

Price, C.; Huston, R.; Meyers, A. D. 2008. From the classroom a new approach to improve technology commercialization in university medical schools, Journal of Commercial Biotechnology 14(2): 96-102. https://doi.org/10.1057/palgrave.jcb.3050086

Rahal, A. D. 2005. Assessment framework for the evaluation and prioritization of university technologies for licensing and commercialization: Dissertation. Florida Institute of Technology.

NASA (The National Aeronautics and Space Administration), 2017. [online], [cited 7 September 2017]. Available from Internet: https://sbir.nasa.gov/solicit/58007/detail $? 11=58014$

Turskis, Z. 2009. Daugiatikslio apsisprendimo metodai statiniu gyvavimo ciklui modeliuoti, habilitacijos procedurai teikiamu mokslo darbu apžvalga. Vilnius, Technika, p. 41. 
Ustinovičius L.; Zavadskas, E. K.; Podvezko, V. 2007. Application of a quantitative multiple criteria decision making (MCDM-1) approach to the analysis of investments in construction, Control and Cybernetics 36: 251-268.

Venture Quest Ld. Online Diagnostic Tools, Importance Tree. 2015. [online], [cited 7 September 2015]. Available from Internet:: http://www.venturequestltd.com/tools.html

WIPO (The World Intellectual Property Organization), 2005. Exchanging value: negotiating technology, licensing agreements.

Zavadskas E. K., Turskis Z., Tamošaitiene J. (2008): Construction Risk Assessmentof Small Scale Objects by Applying the TOPSIS Method with Attributes Values Determined at Intervals. The 8th International Conference "Reliability and Statistic in Transportation and Communication", Latvia. 


\section{Appendix}

Table 1. Meanings of factor values of factor group situation on the market

\begin{tabular}{|c|c|c|c|c|}
\hline \multicolumn{3}{|c|}{ Tech. } & \multirow{2}{*}{ Assessment scale } & \multirow{2}{*}{ Factors } \\
\hline 1 & 2 & & & \\
\hline & & & $\begin{array}{l}\text { Rate by points } 1-5: \\
1-[0-25 \%] \\
2-[26-45 \%] \\
3-[46-65 \%] \\
4-[66-75 \%] \\
5-[76 \%<)\end{array}$ & A1 \\
\hline & & & $\begin{array}{l}\text { Rate by points from } 1-5 \text { : } \\
1 \text { - up to } 20 \% \text { respondents expressed the need; } \\
2 \text { - over } 20 \% \text { respondents expressed the need, a more perfect solution of the } \\
\text { problem is required than it existed so far, but it is not relevant; } \\
3 \text { - over } 30 \% \text { respondents expressed the need, because more perfect solution of } \\
\text { the problem is required than it existed so far; } \\
4-\text { over } 40 \% \text { respondents expressed the need, a consumer desires a tool for the } \\
\text { solution of the problem; } \\
5-\text { over } 50 \% \text { respondents expressed the need, technology could help to solve } \\
\text { a global problem. }\end{array}$ & $\mathrm{A} 2$ \\
\hline & & & $\begin{array}{l}\text { Rate by points from } 1-5 \text { : } \\
1-[0-30 \%] \text { target market is informed on the existence of tech. solution; } \\
2-[31-45 \%] \text { target market is informed on the existence of tech. solution; } \\
3-[46-55 \%] \text { target market is informed on the existence of tech. solution; } \\
4-[66-75 \%] \text { target market is informed on the existence of tech. solution; } \\
5-[86 \%<) \text { target market is informed on the existence of tech. solution; }\end{array}$ & A3 \\
\hline
\end{tabular}

Table 2. Meanings of factor values of factor group value for consumer

\begin{tabular}{|c|c|c|c|c|}
\hline \multicolumn{3}{|c|}{ Tech. } & \multirow{2}{*}{ Assessment scale } & \multirow{2}{*}{$\begin{array}{c}\text { Factor } \\
\mathrm{s}\end{array}$} \\
\hline 1 & 2 & & & \\
\hline & & & $\begin{array}{l}\text { Rate by points from } 1-5 \text { : } \\
1 \text { - less than the currently used alternatives; } \\
2 \text { - slightly less than the currently existing alternatives; } \\
3 \text { - equivalent to the currently existing alternatives; } \\
4 \text { - slightly higher than the currently existing alternatives; } \\
5 \text { - higher than the existing alternatives. }\end{array}$ & B1 \\
\hline & & & $\begin{array}{l}\text { Rate by points from } 1-5 \text { : } \\
1 \text { - more than } 90 \% \text { of the surveyed respondents have a negative opinion or such } \\
\text { kind of a research has not been performed yet; } \\
2 \text { - more than } 50 \% \text { of the surveyed consumers have a negative opinion or such } \\
\text { a research has not been performed yet; } \\
3 \text { - potential customers are either neutral or negative or positive and divided in } \\
\text { equal parts; } \\
4 \text { - more than } 50 \% \text { of the potential customers have a positive opinion; } \\
5 \text {-more than } 90 \% \text { of the respondents have a positive opinion. }\end{array}$ & B2 \\
\hline & & & $\begin{array}{l}\text { Rate by points from } 1-5 \text { : } \\
1 \text { - the method which solves the problems by means of technology is widely } \\
\text { known and applicable; } \\
2 \text { - the method which solves the problems by means of technology is not } \\
\text { perfect; } \\
3 \text { - the method which solves the problems by means of technology is perfected; }\end{array}$ & B3 \\
\hline
\end{tabular}




\begin{tabular}{|c|c|c|}
\hline Tech. & \multirow{2}{*}{ Assessment scale } & \multirow{2}{*}{$\begin{array}{c}\text { Factor } \\
\mathrm{s}\end{array}$} \\
\hline \begin{tabular}{l|l|l}
1 & 2 & 3 \\
\end{tabular} & & \\
\hline & $\begin{array}{l}4 \text { - the method which solves the problems by means of technology is radical or } \\
\text { completely different from the currently existing so far. } \\
5 \text { - technology could change the method used by an industrial branch. }\end{array}$ & \\
\hline & $\begin{array}{l}\text { Rate by points from } 1-5 \text { : } \\
1 \text { - it is very complicated to use; } \\
2 \text { - it is complicated to use; } \\
3 \text { - the level of usage concerning its complexity is similar to the currently } \\
\text { existing alternatives; } \\
4 \text { - it is simple to use; } \\
5 \text { - the usage is absolutely simple; }\end{array}$ & B4 \\
\hline & $\begin{array}{l}\text { Rate by points from } 1-5 \text { : } \\
1 \text { - equivalent to the currently existing alternatives; } \\
2 \text { - slightly higher than the currently existing alternatives; } \\
3 \text { - higher than the currently existing alternatives; } \\
4 \text { - visible relative advantage; } \\
5 \text { - clearly visible relative advantage. }\end{array}$ & B5 \\
\hline
\end{tabular}

Table 3. Meanings of factor values of factor group financial environment

\begin{tabular}{|c|c|c|c|}
\hline \multicolumn{2}{|c|}{ Tech. } & \multirow{2}{*}{ Assessment scale } & \multirow{2}{*}{$\begin{array}{c}\text { Factor } \\
\mathrm{s}\end{array}$} \\
\hline & & & \\
\hline & & $\begin{array}{l}\text { Choose an appropriate factor: } \\
\text { 1-currently available or likely probable financing up to } 20 \% \text { of the required } \\
\text { sum for the total and complete project ; } \\
\text { 2-currently available or likely probable financing [ } 20-40 \% \text { ) of the required } \\
\text { sum for the total and complete project; } \\
3 \text { - currently available or likely probable financing is }[40-60 \% \text { ) of the required } \\
\text { sum for the total and complete project; } \\
\text { 4-currently available or likely probable financing [ } 60-80 \% \text { ) of the required } \\
\text { sum for the total and complete project ; } \\
5 \text { - currently available or likely probable financing [ }[80-100 \%] \text {. }\end{array}$ & $\mathrm{C} 1$ \\
\hline & & $\begin{array}{l}\text { Choose an appropriate range (competitive unit } \operatorname{cost}=\alpha / \beta ; \alpha-\text { competing } \\
\text { product that solves the same problem unit cost; } \beta-\text { technology-based product } \\
\text { unit cost). } \\
1-[0-1] ; \\
2-(1-1.43] \\
3-(1.43-2.5] \\
4-(2.5-5] \\
5-(5<) \text {; }\end{array}$ & $\mathrm{C} 2-$ \\
\hline & & $\begin{array}{l}\text { Choose an appropriate range: } \\
1-\text { less than } 3 \% \text { from the profit earned; } \\
2-[3-10 \%) \text { from the profit earned; } \\
3-[10-15 \%) \text { from the profit earned; } \\
4-[15-25 \%] \text { from the profit earned; } \\
5-\text { more than } 25 \% \text { from the profit earned. }\end{array}$ & C3 \\
\hline & & $\begin{array}{l}\text { Rate from } 1 \text { to } 5 \text { : } \\
1 \text { - impact on product durability was minimal but unused; } \\
2 \text { - the opportunity to leverage product durability was minimal but exploited; } \\
3 \text { - the ability to leverage product durability was moderate and fully exploited; } \\
4 \text { - the potential to leverage product durability was high but not fully exploited; }\end{array}$ & $\mathrm{C} 4$ \\
\hline
\end{tabular}




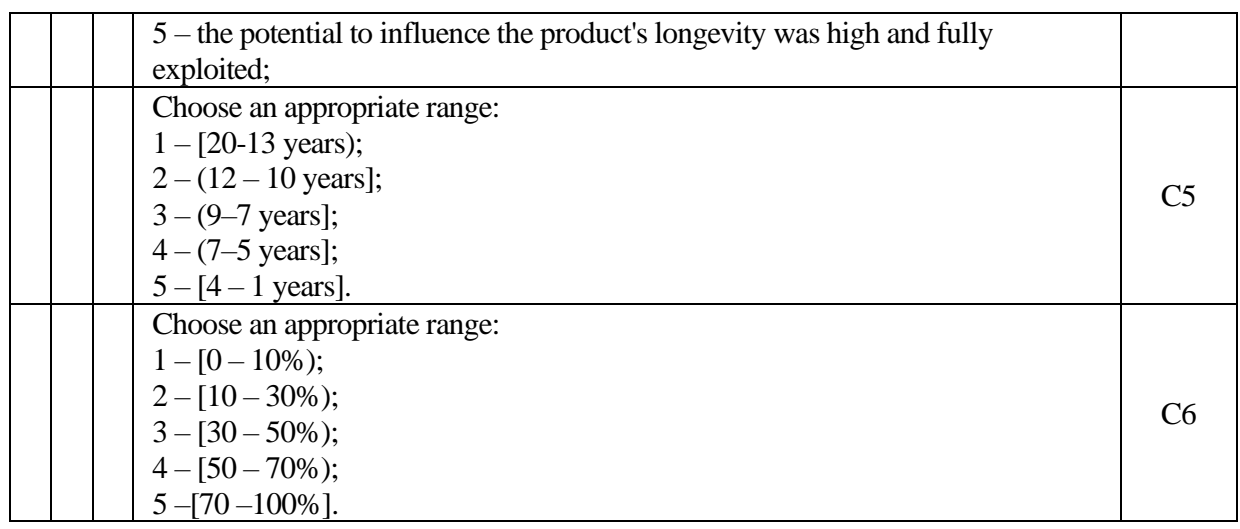

Table 4. Meanings of factor values of factor group competitive environment

\begin{tabular}{|c|c|c|c|c|}
\hline \multicolumn{3}{|c|}{ Tech. } & \multirow{2}{*}{ Assessment scale } & \multirow{2}{*}{$\begin{array}{c}\text { Factor } \\
\mathrm{s}\end{array}$} \\
\hline 1 & 2 & 3 & & \\
\hline & & & $\begin{array}{l}\text { Rate by points from } 1-5: \\
1 \text { - up to } 5 \text { years; } \\
2 \text { - over } 5 \text { years; } \\
3 \text { - up to } 10 \text { years; } \\
4 \text { - over } 10 \text { years; } \\
5 \text { - over } 15 \text { years. }\end{array}$ & D1 \\
\hline & & & $\begin{array}{l}\text { Rate by points from } 1-5 \text { : } \\
1 \text { - technology is uncomplicated to identify, copy, manufacture; } \\
2 \text { - technology is uncomplicated to copy, manufacture; } \\
3 \text { - technology is relatively uncomplicated to identify, copy, manufacture; } \\
4-\text { technology is integrated, complicated to copy, manufacture; } \\
5 \text { - technology is integrated, extremely complicated to copy, manufacture }\end{array}$ & D2 \\
\hline & & & $\begin{array}{l}\text { Rate by points from } 1-5 ; \\
1 \text { - market occupied } 100 \% \\
2 \text { - market occupied } 80 \% \\
3 \text { - market occupied } 60 \% \\
4 \text { - market occupied } 40 \% \\
5 \text { - market occupied } 20 \%\end{array}$ & D3 \\
\hline
\end{tabular}

Table 5. Meanings of factor values of factor group technology features

\begin{tabular}{|c|c|c|c|}
\hline \multicolumn{2}{|c|}{ Tech. } & \multirow{2}{*}{ Assessment scale } & \multirow{2}{*}{$\begin{array}{c}\text { Factor } \\
\mathrm{s}\end{array}$} \\
\hline \begin{tabular}{l|l}
1 & 2 \\
\end{tabular} & & & \\
\hline & & $\begin{array}{l}\text { Rate by points } 1-5 \text { : } \\
1 \text { - technology covers a lot of groups processes; } \\
2 \text { - technology includes a few groups of phenomena or/and processes; } \\
3 \text { - technology includes a group of phenomena or/and processes; } \\
4 \text { - technology includes a few of phenomena, processes; } \\
5 \text { - technology includes one processes; }\end{array}$ & E1 \\
\hline & & $\begin{array}{l}\text { Rate by points from } 1-5 \text { : } \\
1-\text { technology is dependent on geographic/ climatic circumstances, modification } \\
\text { is not possible; } \\
2-\text { technology is dependent on geographic / climatic circumstances, } \\
\text { modification is possible, but too expensive; }\end{array}$ & E2 \\
\hline
\end{tabular}




\begin{tabular}{|c|c|c|l|c|}
\hline \multicolumn{2}{|c|}{ Tech. } & \multicolumn{1}{c|}{ Assessment scale } & Factor \\
\hline 1 & 2 & 3 & & $\mathrm{~s}$ \\
\hline & & & 3-technology depends on geographic / climatic circumstances , but modification & \\
& & is possible; & \\
& & 4-technology is dependent minimally on geographic / climatic circumstances, & \\
& & minimal modification is required; & \\
& & 5-technology is independent on geographic / climatic circumstances; & \\
\hline
\end{tabular}

Table 6. Meanings of factor values of factor group technology developers' competence

\begin{tabular}{|c|c|c|c|}
\hline \multicolumn{2}{|c|}{ Tech. } & \multirow{2}{*}{ Assessment scale } & \multirow{2}{*}{$\begin{array}{c}\text { Factor } \\
\mathrm{s}\end{array}$} \\
\hline 1 & \begin{tabular}{l|l}
2 & 3
\end{tabular} & & \\
\hline & & $\begin{array}{l}\text { Rate by points from } 1-5 \text { the competence of the Head of the Division /a } \\
\text { person in charge of this particular activity: } \\
1 \text { - Master Degree and work experience in this particular field }[1-4 \text { years]; } \\
2 \text { - Master Degree and work experience in this particular field ( } 4-9 \text { years]; } \\
3 \text { - Master Degree in this particular field and work experience for } 9 \text { years }<\text { or } \\
\text { Doctorate Degree and work experience in this field ( } 4-9 \text { years); } \\
4 \text { - Doctorate Degree and work experience in this particular field for } 9 \text { years }<\text {; } \\
5 \text { - Professor and work experience in this particular field for } 4 \text { years }<\text {. }\end{array}$ & $\mathrm{F} 1$ \\
\hline & & $\begin{array}{l}\text { Rate by points from } 1-5 \text { the competence of the Head of the Division /a } \\
\text { person in charge of this particular activity : } \\
1 \text { - University Degree in this particular field and work experience < } 1 \text { year, } \\
\text { but a division / a person in charge of the activity are missing; } \\
2 \text { - University Degree in this particular field and work experience [ } 1-4 \\
\text { years]; } \\
3 \text {-University Degree in this particular field and work experience ( } 4-9 \text { years] } \\
\text { or Master Degree in this particular field and work experience }(1-4 \text { years]; } \\
4 \text {-Master Degree in this particular field and work experience for } 4 \text { years <or } \\
\text { Doctoral Degree in this particular field or (higher degree) and work experience } \\
\text { up to } 4 \text { years; } \\
5 \text { - Doctoral Degree (or higher degree) and work experience for 4years <. }\end{array}$ & $\mathrm{F} 2$ \\
\hline & & $\begin{array}{l}\text { Rate by points from } 1-5 \text { the competence of the Head of the Division /a } \\
\text { person in charge of this particular activity. } \\
1 \text { - University Degree in Engineering or Social Sciences and work experience } \\
\text { in this particular field for < } 1 \text { year or a person in charge of this particular } \\
\text { activity is missing. } \\
2 \text { - University Degree in Engineering or Social Sciences and work experience } \\
\text { in this particular field } 1 \text { - } 4 \text { years; } \\
3 \text { - Master Degree in Engineering or Social Sciences and work experience in } \\
\text { this particular field } 4-9 \text { years; } \\
4 \text { - Master Degree in Engineering or Social Sciences and work experience in } \\
\text { this particular field up to } 9 \text { <years or Doctoral Degree (or higher degree)in } \\
\text { Engineering or Social Sciences and work experience in this particular field for } \\
4 \text { years; } \\
5 \text {-Doctoral Degree (or higher degree) in Engineering or Social Sciences and } \\
\text { work experience for } 4 \text { years.<.; }\end{array}$ & F3 \\
\hline & & $\begin{array}{l}\text { Rate by points from } 1-5 \text { the competence of the Head of the Division /a } \\
\text { person in charge of this particular activity: } \\
1 \text { - University Degree in this particular field and work experience < } 1 \text { year or a } \\
\text { division / a person in charge of this particular activity is missing; } \\
2 \text { - University Degree in this particular field and work experience [ } 1-4 \text { years] } \\
\text { or Master Degree in this particular field and work experience up to } 1 \text { year; }\end{array}$ & $\mathrm{F} 4$ \\
\hline
\end{tabular}




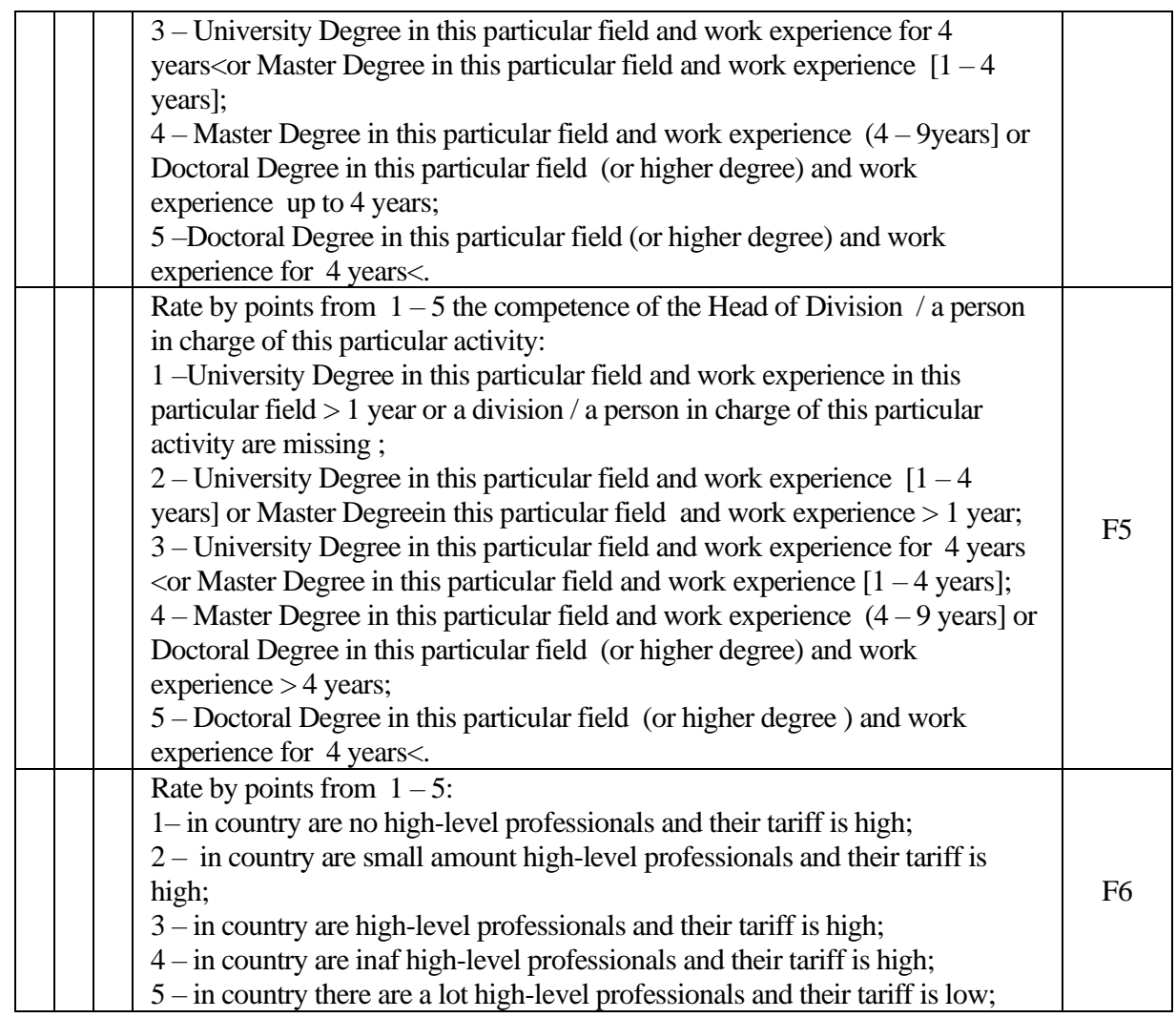

Table 7. Meanings of factor values of factor group legal environment, when technology is legally not protected

\begin{tabular}{|c|c|c|c|}
\hline \multicolumn{2}{|c|}{ Tech. } & \multirow{2}{*}{ Assessment scale } & \multirow{2}{*}{$\begin{array}{c}\text { Factor } \\
\mathrm{s}\end{array}$} \\
\hline 1 & \begin{tabular}{l|l}
2 & 3 \\
\end{tabular} & & \\
\hline & & $\begin{array}{l}\text { Rate by points from } 1-5 \text { considering Ease of Doing Business Score: } \\
\text { http://www.doingbusiness.org/rankings ( } 190 \text { countries }) \text { : } \\
1-(152-189 \text { places }] \\
2-(114-152 \text { places }] \\
3-(76-114 \text { places }] \\
4-(38-76 \text { places }] \\
5-[1-38 \text { places }]\end{array}$ & G1 \\
\hline & & $\begin{array}{l}\text { Rate by points from } 1-5 \text { : } \\
1-\text { can be tailored for solution one problem, but effort is needed.; } \\
2 \text { - benefit is uncertain in one field of activity; } \\
3 \text { - beneficial in one field of activity; } \\
4 \text { - beneficial in several fields of activities, but the level of benefit in one of } \\
\text { the activities is extremely evident; } \\
5 \text { - benefit is especially evident in several fields of activities. }\end{array}$ & $\mathrm{G} 2$ \\
\hline & & $\begin{array}{l}\text { When evaluating choose } 0 \text { or } 1 \text { : } \\
0 \text { - technology is exposed; } \\
1 \text { - technology is confidential. }\end{array}$ & G3 \\
\hline & & $\begin{array}{l}\text { When evaluating choose } 0 \text { or } 1 \text { : } \\
0 \text { - indistinct difference }\end{array}$ & G4 \\
\hline
\end{tabular}




\begin{tabular}{|c|c|c|c|}
\hline \multicolumn{2}{|c|}{ Tech. } & \multirow{2}{*}{ Assessment scale } & \multirow{2}{*}{$\begin{array}{c}\text { Factor } \\
\mathrm{s}\end{array}$} \\
\hline & & & \\
\hline & & 1- difference is obvious & \\
\hline & & $\begin{array}{l}\text { Rate by points from } 1-5 \text { : } \\
1 \text { - regional patents can cost between } € 10,000 \text { and } € 25,000 \text {; } \\
2 \text { - USA patent can cost from } \$ 900 \text { to between } \$ 5,000 \text { and } \$ 10,000+\text { with the } \\
\text { help of patent lawyers, but depends on the type of patent and complexity of the } \\
\text { invention. } \\
3 \text { - regarding other countries substantially more expensive - } 2000 \text { iki } 5000 € \\
4 \text { - Lithuanian patent cost } 300-400 \text { Eur; } \\
5 \text { - Patent Cooperation Treaty (PCT). }\end{array}$ & G5 \\
\hline & & $\begin{array}{l}0 \text { - the period of validity of patent in biotechnology projects interfere with } \\
\text { commercialization processes. } \\
1 \text { - the patent validity period interacts positively with commercialization } \\
\text { processes. }\end{array}$ & G6 \\
\hline
\end{tabular}

Table 8. Meanings of factor values of factor group inventor/-s profile

\begin{tabular}{|c|c|c|c|c|}
\hline \multicolumn{3}{|c|}{ Tech. } & \multirow{2}{*}{ Assessment scale } & \multirow{2}{*}{ Factors } \\
\hline 1 & 2 & & & \\
\hline & & & $\begin{array}{l}\text { Rate by points from } 1-5 \text { : } \\
1-[0-4 \text { years }] ; \\
\text { 2- }(4-9 \text { years }] ; \\
\text { 3- }(9-19 \text { years }] ; \\
\text { 4- }(19-40 \text { years }] \\
\text { 5- }(40 \text { <years }) .\end{array}$ & H1 \\
\hline & & & $\begin{array}{l}\text { Rate by points from } 1-5 \text { Inventor's academic recognition, considering Web } \\
\text { of Science h-index (https://publons.com): } \\
1-1-9 \\
2-10-19 \\
3-20-29 \\
4-30-49 \\
5-50<\end{array}$ & $\mathrm{H} 2$ \\
\hline & & & $\begin{array}{l}\text { Rate by points from } 1-5 \text { : } \\
1-[0-10 \%) ; \\
2-[10-30 \%) ; \\
3-[30-50 \%) ; \\
4-[50-70 \%) ; \\
5-[70-100 \%]\end{array}$ & $\mathrm{H} 3$ \\
\hline & & & $\begin{array}{l}\text { Rate by points from } 1-5 \text { : } \\
1-[0-10 \%) ; \\
2-[10-30 \%) ; \\
3-[30-50 \%) ; \\
4-[50-70 \%) ; \\
5-[70-100 \%]\end{array}$ & $\mathrm{H} 4$ \\
\hline
\end{tabular}

Table 9. Meanings of factor values of factor group internal policy of the institution

\begin{tabular}{|c|c|c|l|c|}
\hline \multicolumn{2}{|c|}{ Tech. } & \multicolumn{1}{|c|}{ Assessment scale } & Factors \\
\hline 1 & 2 & 3 & & I1 \\
\hline & & & $\begin{array}{l}\text { Rate by points from 1-5: } \\
1-\text { activity of the institution is unrelated with technical commercialization } \\
\text { and no plans for future activities in this field; }\end{array}$ & \\
\hline
\end{tabular}




\begin{tabular}{|c|c|c|c|}
\hline \multicolumn{2}{|c|}{ Tech. } & \multirow{2}{*}{ Assessment scale } & \multirow{2}{*}{ Factors } \\
\hline & & & \\
\hline & & $\begin{array}{l}2 \text { - activity of the institution is unrelated with technical commercialisation, but } \\
\text { in future there are plans to expand this particular activity; } \\
3 \text { - the institution is reorganizing its activities; one new field of activity is } \\
\text { connected with technical commercialisation } \\
4 \text { - the activities of the institution are developed in several directions; one of } \\
\text { the activities is directly related to technical commercialisation } \\
5 \text { - technical commercialisation project corresponds completely the strategy } \\
\text { and current activities of the institution. }\end{array}$ & \\
\hline & & $\begin{array}{l}\text { Rate by points from } 1-5 \text { : } \\
1 \text { - terms and conditions of the institution are totally unacceptable for the } \\
\text { inventor; neither one nor the other side is inclined to compromise; } \\
2 \text {-terms and conditions of the institution are unacceptable for the inventor, } \\
\text { but there is a minimal probability to compromise; } \\
3 \text { - because of the unsatisfactory terms and conditions, one side or the other is } \\
\text { likely to compromise; } \\
4-\text { the terms and conditions of the institution are acceptable in principal, but } \\
\text { the minimal inadmissibility prevails; } \\
5 \text { - terms and conditions of the institution totally satisfies the inventor. }\end{array}$ & I2 \\
\hline & & $\begin{array}{l}\text { Rate by points from } 1-5 \text { : } \\
1 \text { - institution is not active in this particular field, commercialisation of } \\
\text { technologies is targeted for future; } \\
2 \text { - institution commercializes technologies, but this activity is not profitable } \\
3 \text { - institution commercializes technologies, income covers investments, but } \\
\text { its activities are not profitable; } \\
4 \text { - institution commercializes technologies, this field of activity is profitable; } \\
5 \text { - Institution commercializes technologies, the activity of the institution is } \\
\text { extremely profitable. }\end{array}$ & $\mathrm{I} 3$ \\
\hline
\end{tabular}

